\title{
GLL
}

00

\section{MODERNIZATION OF BUILDINGS IN A SPECIFIC AREA, USING PHOTOGRAMMETRIC METHODS}

\author{
Izabela Piech, Mateusz Kopciara
}

\section{Summary}

Photogrammetry is a rapidly developing field of science, using new technologies such as unmanned aerial vehicles (UAVs), and digital cameras. This field deals with obtaining reliable information about physical objects and their surroundings by means of recording, measuring and interpreting images [Markiewicz et al. 2012]. Currently, unmanned aerial vehicles are used not only for taking amateur or professional commemorative aerial photographs, but they also find much more specialized applications. Among these applications, we can distinguish air pollution inspections (carried out, among others, by municipal police), border inspections, search for missing persons, and many other uses [Nowobilski 2020]. UAV photogrammetry can be understood as a new photogrammetric measurement tool. It opens up various new applications in the field of short-range imaging, combining aerial and ground photogrammetry; and it also introduces low-cost alternatives to classical aerial photogrammetry with crew [Eisenbeiß 2009]. Today, not everyone can afford photogrammetric flight campaigns, which require more time and money. Although UAVs are not used on a large scale in surveying, still, their development, the possibility of using them for surveying works, the accessibility and ease of application, as well as the development of the cameras themselves, convince more and more surveyors to use them more broadly in the performance of geodetic works.

Unmanned aerial vehicles are used to perform photogrammetric mission flights, thanks to which photos of the land surface are obtained. This allows for the generation of orthophotos, and even three-dimensional terrain models, enabling further analysis of the studied area.

The aim of this study was to present the possibility of using UAVs for the purpose of updating land and buildings records in a specific area. Based on the photos obtained during the photogrammetric mission, an orthophotomap had been generated, which was subsequently used for the modernisation of records and updating the functions of buildings and areas. Then, all the buildings on the land plots were grouped according to their function, status, construction material, number of storeys, and area calculated from the roof surface. 37 land plots were covered by the measurement. 5 selected plots were used for the purpose of this publication.

\section{Keywords}

$\mathrm{UAV} \bullet$ drone $\bullet$ photogrammetry $\bullet$ orthophotomap • land and building records 


\section{Introduction}

Unmanned aerial vehicles, otherwise known as drones, constitute a new addition to photogrammetry and remote sensing. Due to the broad range of possibilities of using UAVs to take photos, scientific publications related to this topic are steadily increasing in number. The article entitled 'UAV Photogrammetry' by Henri Eisenbeiß deals with the topic of using UAV systems as photogrammetric platforms for data acquisition [Eisenbeiß 2009]. The author of the aforementioned publication presents the possibilities of using various platforms to generate orthophotomaps, and he examines their usefulness. The study shows that not all software packages can be used for all possible UAV photogrammetry applications. Often, it is only the combination of several packets that is able to completely process the data set. These limitations of the software packages available on the market are due to the fact that they are designed for standard aerial photography, and do not support arbitrary image configurations [Eisenbeiß 2009]. The author of the article also draws attention to the limitations of unmanned platforms, in which the accuracy assumptions of the measurements play a significant role - and for drones, the assumed accuracy standards may be unattainable or the cost of achieving them would be equal to or greater than the existing classic solutions [Burdziakowski 2016].

In his article 'Unmanned aerial vehicles in the control of construction objects', Tomasz Nowobilski draws attention to a number of advantages of using drones for photogrammetric mission flights related to construction objects. These include, among others: quick collection of detailed photographic stills and film material of the analysed object, easy access of the UAV to some objects located in places otherwise inaccessible from the ground (e.g. located at heights, or above water), as well as the ability to take photographs in difficult conditions. The author also lists the disadvantages of flying over buildings, which are often related to unpredictable behaviour by third parties and the risk of the 'drone' being attacked, for instance by birds [Nowobilski 2020].

The issue of the accuracy of the measurement performed by means of an UAV, which is required to use the images obtained during the photogrammetric mission flight, as well as to adapt these measurements to the requirements of the Land and Building Records (EGiB), is included in the publication entitled 'Development of the graphic part of the land and building records based on aerial photos from the UAV' by A. Plicht, M. Wyczałek, and I. Wyczałek. The authors noted that as part of the photogrammetric mission flight, and depending on the photogrammetric software used, in order to ensure the credibility of the study results, photos should be taken with a calibrated photographic set, as well as an appropriate network of photopoints should be set up before performing the photogrammetric mission flight proper. If these two conditions are neglected, the resulting studies will be burdened with excessive error, even if visually they might seem correct [Plichta et al. 2017]. With appropriate conditions and a correctly executed photogrammetric mission flight, an orthophotomap is created from the photos. On the basis of such material, it is possible to carry out the EGiB content verification process, and at the same time it becomes possible to supplement the BDOT500 databases. The authors also noted that the comparison of the results 
of the field measurement with the vectorially marked locations of the points showed that the differences did not exceed 3 pixels (in extreme cases), and on average less than 1.5 pixels with a terrain dimension of $5 \mathrm{~cm}$. This level of accuracy reveals that the results, related mainly to the buildings' data base of EGiB, entirely fulfil the assumption, namely that the use of high-resolution digital images fully meets the legal assumptions adopted for the analysed scope of information [Plichta et al. 2017].

A significant part of the articles related to 'drones' or the elaboration of the measurement results itself confirm the flexibility of UAV use, as well as the rapid and large prospects for the development of the 'drone' industry.

Currently, the geodetic law in force in Poland requires the public administration body to keep and update the land and building survey. The records are established and kept in an IT system based on computer databases [Regulation of the Minister of Regional Development and Construction of March 29, 2001 - Rozporządzenie 2001]. These databases are part of the geodetic and cartographic resource. On the basis of the online databases created for each district, reports are developed showing data on the land and building records, files of buildings and premises as well as cadastral maps. The Regulation of March 29, 2001 on the land and building records defines the purpose and procedure for introducing changes, which, as a rule, may be carried out either pursuant to a request, or ex officio [Noszczyk and Hernik 2016]. Updating the records of land and buildings serves the purpose of bringing the status that appears in the records to the actual format - i.e. the factual and legal status. This involves introducing the documented changes to the records database in order to replace any data that is inconsistent with the actual condition, legal status, or applicable technical standards with relevant data that is consistent with the above-mentioned statuses, and also to eliminate any erroneous data [Leśkiewicz 2016]. One of the ways of performing such an update is the modernisation of the Land and Building Records.

According to the legal regulations, modernization is a set of technical, organizational and administrative activities aimed at supplementing the land records database in accordance with the requirements of the Regulation, modifying the existing data and improving the functioning of the system that is supporting the records database. One of the basic tasks of modernization is to designate or update the boundaries of cadastral plots, which often do not match the existing status, and may sometimes be even missing altogether, or may be shown as passing through the building, which is unacceptable. Very often, cadastral maps have a shape and size and feature a number of buildings on one plot that differ from the actual state. While performing an update, we may often notice that one or even a dozen buildings are missing from the map.

The main objective of the EGiB database modernization is primarily to determine the size i.e. the area of land for individual plots, according to their actual use [Noszczyk and Hernik 2016]. The land listed in the records is divided into: arable land, woodland and forest, built-up and urbanized land, semi-natural areas, wetlands and water bodies, and other areas. Very often, on cadastral maps, we may notice inaccuracies in the designation of land (sites) under the buildings, or its complete absence. Many properties have arable land designated in the sites where the buildings are standing, which is contrary 
to the requirements of the EGiB database. This is due to deficiencies in updating and introducing the latest buildings to the map, or the lack of systematic modification of the database. As a result, shortages in taxes appear in the municipal budget, and large disproportions occur in paying for land between neighbours who own the same kind of built-up land, resulting from erroneous use (typically, farming) featured under the existing building. Each building listed in the Land and Building Records must have its proper function designated, as well as: area calculated from its contours, building status, year of construction, along with the construction material and other additional attributes. In accordance with the Regulation on Land and Building Records, building functions can be divided into type, class, function, and attribute values (Tables 1,2).

Table 1. Types of buildings and values of their attributes

\begin{tabular}{|c|l|}
\hline Value of the attribute & \multicolumn{1}{c|}{ Type of the building } \\
\hline 101 & Industrial buildings \\
\hline 102 & Transportation and communication infrastructure buildings \\
\hline 103 & Commercial - retail and service buildings \\
\hline 104 & Storage tanks, silos and warehouses \\
\hline 105 & Office buildings \\
\hline 106 & Hospital and other health care infrastructure buildings \\
\hline 107 & $\begin{array}{l}\text { Education, science, and culture infrastructure buildings and sports } \\
\text { infrastructure buildings }\end{array}$ \\
\hline 108 & Production, services, and auxiliary infrastructure buildings for agriculture \\
\hline 109 & Other non-residential buildings \\
\hline 110 & Residential buildings \\
\hline
\end{tabular}

Table 2. Functions and values of attributes for residential buildings and farming infrastructure buildings

\begin{tabular}{|c|c|}
\hline Value of the attribute & Building's function \\
\hline \multicolumn{2}{|r|}{ Residential buildings, with one, two, three, and more units } \\
\hline 1110.Dj & Single-family building \\
\hline 1110.DI & Holiday home \\
\hline 1110.Ls & Forester's lodge \\
\hline 1110.In & Other single-family residential buildings \\
\hline 1121.Db & Two-unit residential building \\
\hline 1122.Dw & Tree or more unit residential building \\
\hline \multicolumn{2}{|r|}{ Farming infrastructure buildings } \\
\hline 1271.Bg & Storage building in a farmstead \\
\hline 1271.Bp & Livestock building in a farmstead \\
\hline
\end{tabular}




\begin{tabular}{|l|l|}
\hline 1271.St & Horse stables building \\
\hline 1271.Sz & Hothouse or greenhouse \\
\hline 1271.In & Other buildings in a farmstead \\
\hline
\end{tabular}

Each of the types, classes and functions has its own unique attribute value, which is meant to increase the legibility, and accentuate the difference between similar attributes. Each function of the building represents its use and purpose.

\section{Characteristics of the studied area}

The area of research on which the photogrammetric photogrammetric mission flight was performed with the use of a drone was the village of Tokarnia, located in the Świętokrzyskie Region (województwo), in the Kielce district (powiat), in the Chęciny municipality (gmina). The village is located south of the city of Chęciny, and also south-west of the provincial city of Kielce. The measurement range over the village is 3 $\mathrm{km}$ long and $0.5 \mathrm{~km}$ wide. Its characteristic feature is the presence of numerous mixed buildings, combined with the presence of afforestation and plantings (Fig. 1).

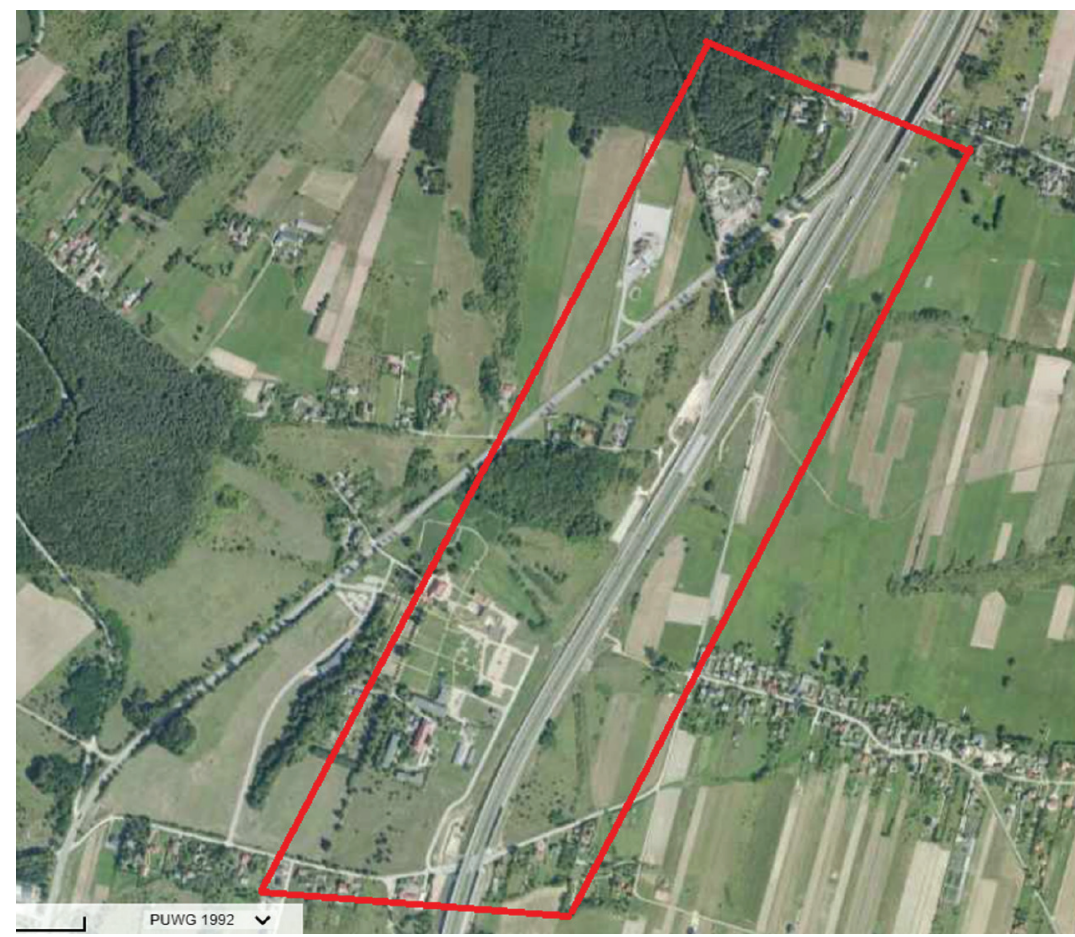

Source: www.mapy.geoportal.gov.pl

Fig. 1. The area of flight mission performed, shown against the Chęciny municipality 
The area of the photogrammetric mission flight is characterized by a varied topography.

In the upper part, the height reaches 286 meters above sea level, while in the lower part it drops significantly and amounts to 197 meters above sea level. During the raid, it was necessary to properly set the flight's height and plan the flight's route.

\section{Methodology}

For the purpose of making an orthophotomap, images from the GRYF unmanned aerial vehicle flight carried out in 2015 over the village of Tokarnia were made available by FlyTech UAV company based in Kraków.

The GRYF unmanned aerial vehicle enables vertical take-off and landing, and therefore it can be used in places with a small area, or in places where the maneuvering room is limited. GRYF has a manual as well as an autonomous flight mode, and photos or other data are transmitted directly during the measurement [Piech et al. 2018]. Its characteristic feature is that it possesses a wide range of applications, which allows the drone to be adapted to various weather conditions, as well as facilitating the transport of various cameras or sensors.

To take pictures from the UAV deck, a Sony camera was used, coupled with the ILCE - 6000 with the Fast Hybrid AF system, which includes the advantages of AF systems based on phase and contrast detection. This camera facilitates very sharp observation of objects, both during the recording, and when taking the photos (at a speed of as many as 11 frames per second) [Piech et al. 2018]. This device is equipped with one of the best $4 \mathrm{D}$ FOCUS technologies available, enabling the combination of an extensive coverage zone of the focus sensor, fast operation of the Fast Hybrid system, and better prediction of focus. Also, the BIZON X processor installed in this camera model significantly increases the speed of the camera and faithfully reproduces textures, and thanks to the selective noise suppression in certain areas, it increases the sharpness of the image, both photographic and film, which is necessary for obtaining good quality photos. The a6000 body installed in the camera is one of the most versatile interchangeable lens cameras available. This is partly due to the super-fast AF system. Focusing takes only 0.06 seconds, so the photos are always sharp and clear [www.sony.pl].

\subsection{Elaboration of the obtained data}

The first stage of work was to make a selection - from almost 500 photos provided by the Krakow company FlyTech - of 295 photos that showed the buildings and places where the points of the network were clearly photographed. Each photo had BLH coordinates and geographic coordinates on the WGS84 ellipsoid. In addition, the materials contained the point coordinates of the geodetic control network, and data on the performed photogrammetric mission flight. Then, carefully selected photos were uploaded to Agisoft PhotoScan using the Add Photos tool. The next step was to enter the coordinates of 295 photos into the program, which was necessary in order to 
locate them in space, and in relation to each other. The following step in the processing of the results entailed combining neighbouring photos into blocks, in order to obtain a sparse point cloud. The coordinates of photopoints were imported on the obtained point cloud by selecting the coordinate system as the WGS84 ellipsoid. Subsequently, these photo points have been marked in the photos. This was one of the longest activities during the development of the orthophotomap, because the given photopoint was very often present in several photosgraph, where it had to be marked in exactly the same location (Fig. 2).

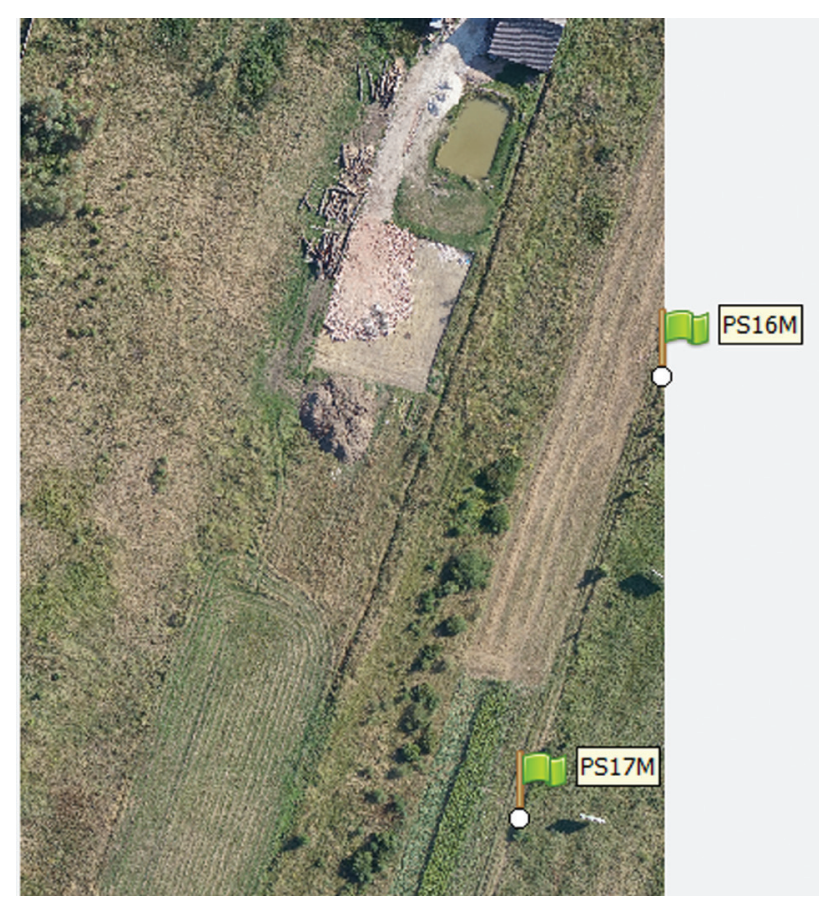

Source: Authors' study

Fig. 2. Location of the marked photopoints in one of the photographs

It was a very important stage of the study, as the inaccurate location of the points would have resulted in gross errors, thus leading to low (and thus insufficient) accuracy of the generated orthophotomap. The photos feature 22 points positioned on the network, where a location error of $0.002 \mathrm{~m}$ was obtained (Fig. 3 ).

Obtaining the aforementioned level of error made it possible to generate a dense point cloud (Fig. 4).

The next step in the development of the project was to build the textures, and this function enabled us to combine the photographs at their junction. With the help of the DTM model created at an earlier stage, and based on building the textures, it was 
possible to start developing the orthophotomap. The generated orthophotomap was saved to a file with the .tif extension (Fig. 5), and its accuracy was $3.25 \mathrm{~cm} / \mathrm{pix}$.

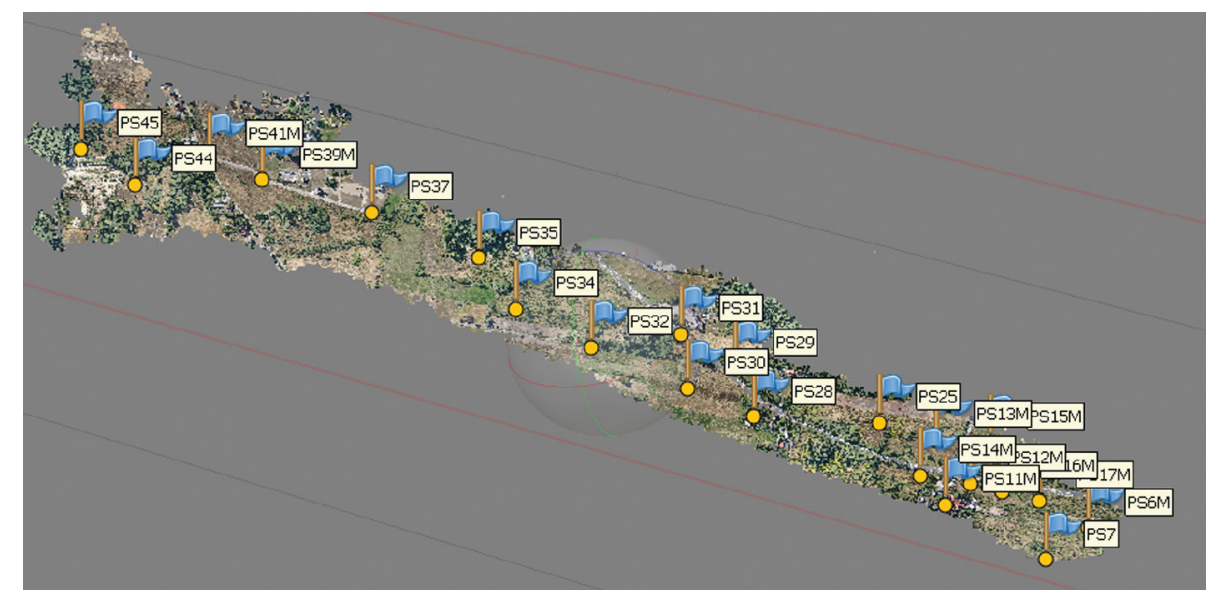

Source: Authors' study

Fig. 3. Location of all the points of the geodetic control network in the model

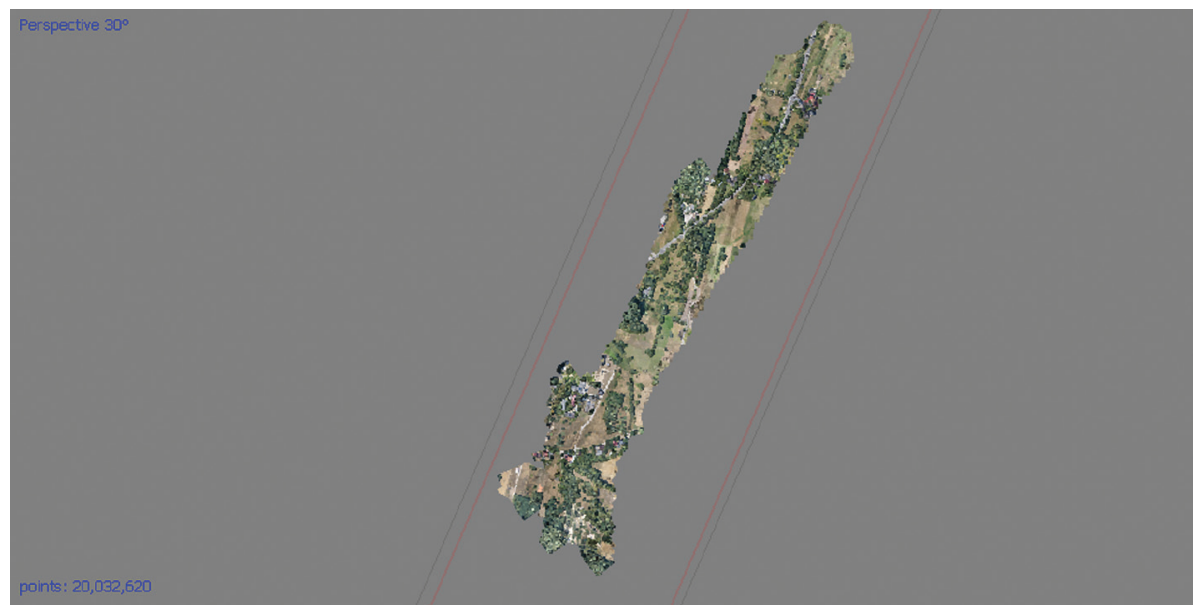

Source: Authors' study

Fig. 4. Dense point cloud 


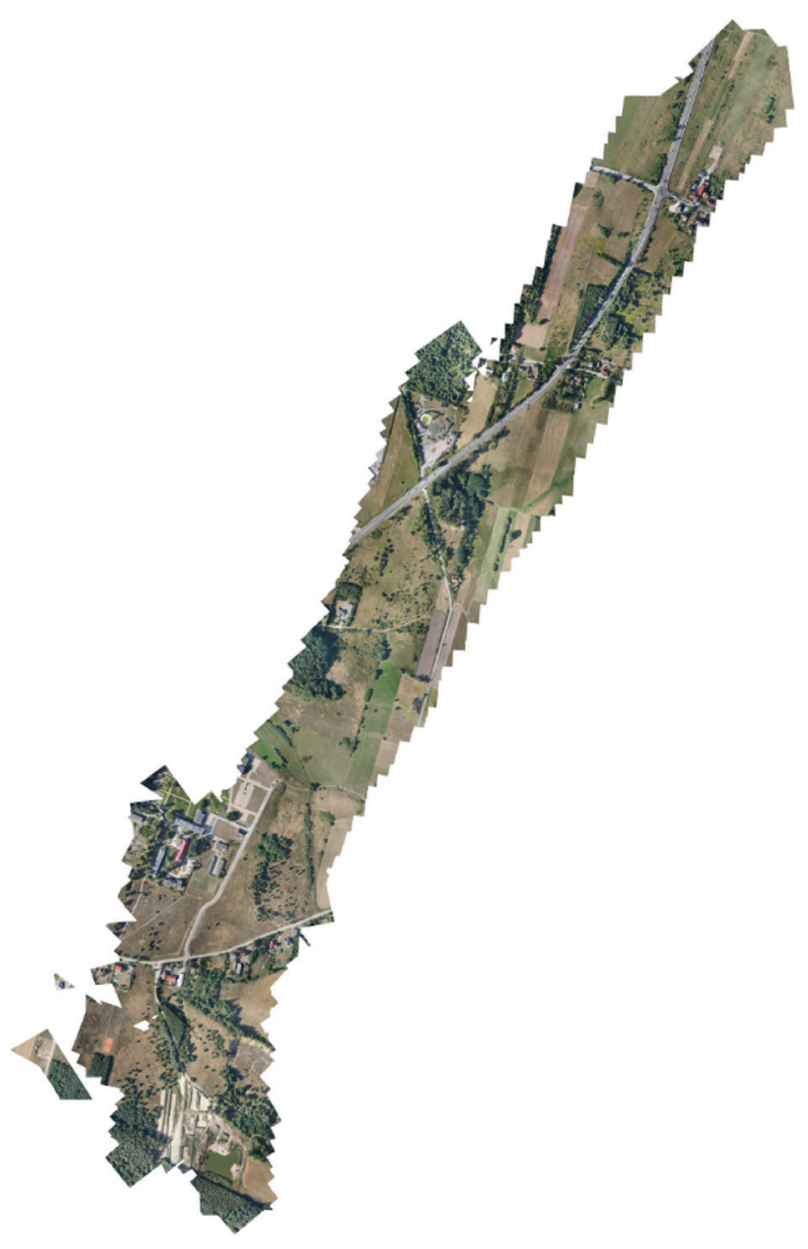

Source: Authors' study

Fig. 5. Orthophotomap developed based on an UAV mission flight

\section{Research results}

Based on the developed orthophotomap of the village of Tokarnia, the identification of the functions of the buildings began. Thanks to the use of a high-quality camera mounted on the flying platform, the identification of virtually every building was satisfactory, and it facilitated obtaining most of the information about a given object. When determining the functions of the buildings and the attributes thereof, the available map backgrounds as well as the layers provided by Geoportal and Google Maps were used.

When determining functions of the buildings, status of the buildings, the materials from which the buildings were constructed, floors and surfaces were additionally established. These data are summarized in a tabular format, corresponding to each of the 
sketches prepared on the basis of the orthophotomap. The sketches show the outlines of the exterior of the building in red, following which the area in square meters has been calculated. Additionally, each building is described with a symbol corresponding to its function and the number of storeys (marked in red inside the building contours). For greater visibility, the plot boundaries are marked in white on the sketches, and also described inside with a number assigned to plots, successively from 1 to 5 (Figs 6-10). Building objects that do not constitute a subject of records - due to their area or type - are marked in green on the sketches and described as BNE (i.e. non-register buildings). Due to the inability to unequivocally diagnose some of the attributes, such as construction material or the number of storeys, some fields in the tables were left without an attribute and marked with a dash (Tables 3-7).

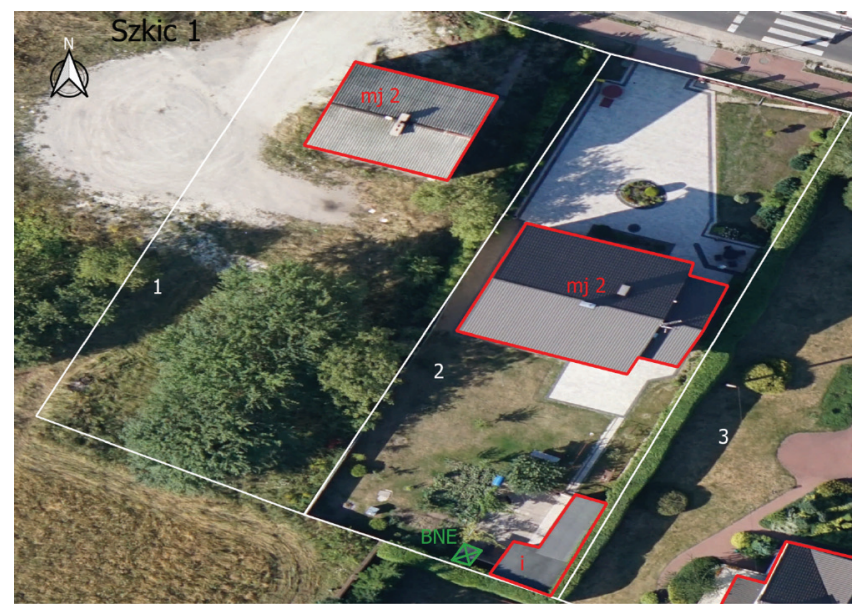

Source: Authors'study

Fig. 6. Sketch No. 1

Table 3. Attributes of buildings in Sketch No. 1

\begin{tabular}{|c|l|l|c|c|c|}
\hline $\begin{array}{c}\text { Plot } \\
\text { number }\end{array}$ & Building status & Building's function & Material & Number of storeys & $\begin{array}{c}\text { Area } \\
{\left[\mathrm{m}^{2}\right]}\end{array}$ \\
\hline 1 & $\begin{array}{l}\text { Construction } \\
\text { completed }\end{array}$ & Single-family building & Brick & 2 & 89.28 \\
\hline \multirow{2}{*}{2} & $\begin{array}{l}\text { Construction } \\
\text { completed }\end{array}$ & Single-family building & Brick & 2 & 163.02 \\
\cline { 2 - 6 } & $\begin{array}{l}\text { Construction } \\
\text { completed }\end{array}$ & $\begin{array}{l}\text { Building with no other } \\
\text { functional attribute } \\
\text { (FSB) assigned }\end{array}$ & Brick & 1 & 30.08 \\
\hline
\end{tabular}




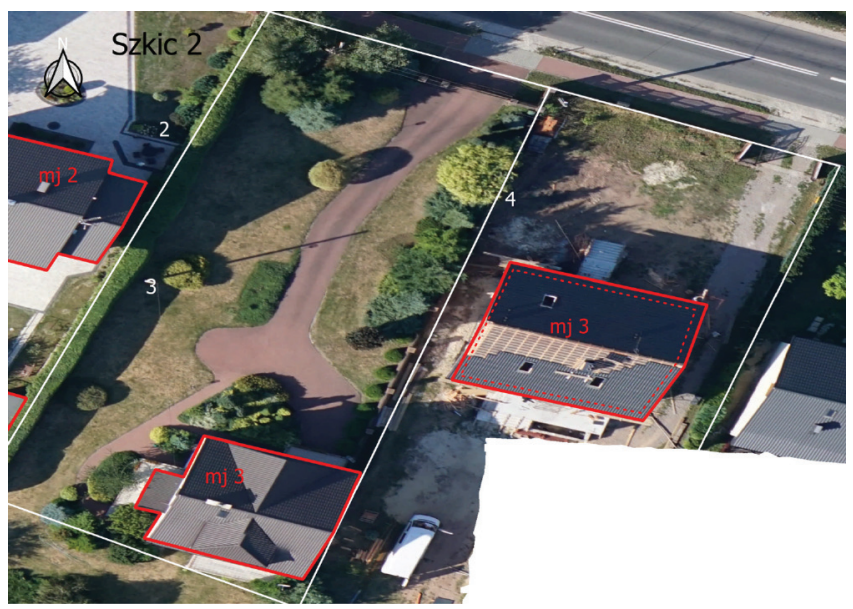

Source: Authors' study

Fig. 7. Sketch No. 2

Table 4. Attributes of buildings in Sketch No. 2

\begin{tabular}{|c|l|l|c|c|c|}
\hline $\begin{array}{c}\text { Plot } \\
\text { number }\end{array}$ & Building status & Building's function & Material & Number of storeys & $\begin{array}{c}\text { Area } \\
{\left[\mathrm{m}^{2}\right]}\end{array}$ \\
\hline 3 & $\begin{array}{l}\text { Construction } \\
\text { completed }\end{array}$ & $\begin{array}{l}\text { Single-family } \\
\text { building }\end{array}$ & Brick & 3 & 128.51 \\
\hline 4 & $\begin{array}{l}\text { Under } \\
\text { construction }\end{array}$ & $\begin{array}{l}\text { Single-family } \\
\text { building }\end{array}$ & Brick & 3 & 168.58 \\
\hline
\end{tabular}

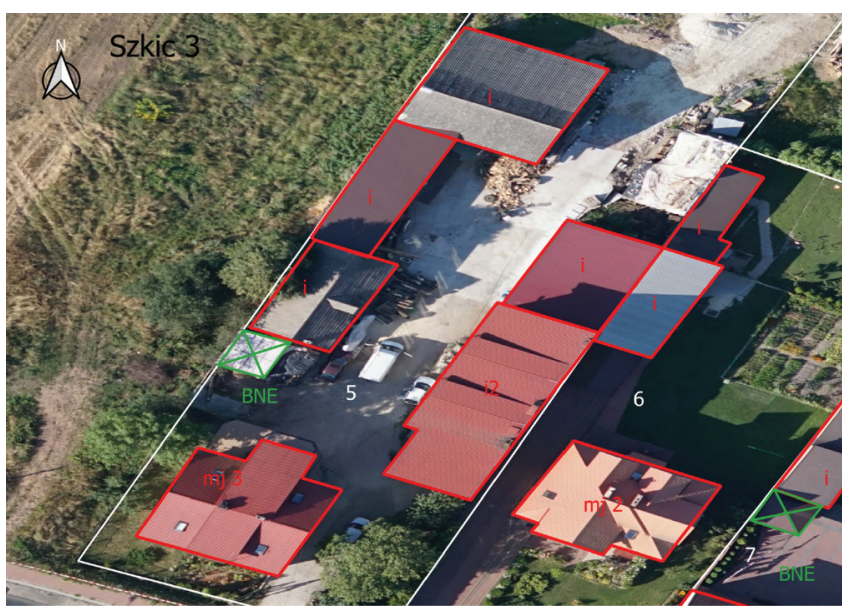

Source: Authors' study

Fig. 8. Sketch No. 3 
Table 5. Attributes of buildings in Sketch No. 3

\begin{tabular}{|c|c|c|c|c|c|}
\hline $\begin{array}{c}\text { Plot } \\
\text { number }\end{array}$ & Building status & Building's function & Material & Number of storeys & $\begin{array}{l}\text { Area } \\
{\left[\mathrm{m}^{2}\right]}\end{array}$ \\
\hline \multirow{6}{*}{5} & $\begin{array}{l}\text { Construction } \\
\text { completed }\end{array}$ & $\begin{array}{l}\text { Single-family } \\
\text { building }\end{array}$ & Brick & 3 & 161.19 \\
\hline & $\begin{array}{l}\text { Construction } \\
\text { completed }\end{array}$ & $\begin{array}{l}\text { Building with no } \\
\text { other functional } \\
\text { attribute (FSB) } \\
\text { assigned }\end{array}$ & Brick & 1 & 84.55 \\
\hline & $\begin{array}{l}\text { Construction } \\
\text { completed }\end{array}$ & $\begin{array}{l}\text { Building with no } \\
\text { other functional } \\
\text { attribute (FSB) } \\
\text { assigned (shed) }\end{array}$ & Brick & 1 & 90.31 \\
\hline & $\begin{array}{l}\text { Construction } \\
\text { completed }\end{array}$ & $\begin{array}{l}\text { Building with no } \\
\text { other functional } \\
\text { attribute (FSB) } \\
\text { assigned }\end{array}$ & Other & 1 & 160.84 \\
\hline & $\begin{array}{l}\text { Construction } \\
\text { completed }\end{array}$ & $\begin{array}{l}\text { Building with no } \\
\text { other functional } \\
\text { attribute (FSB) } \\
\text { assigned }\end{array}$ & Brick & 1 & 101.41 \\
\hline & $\begin{array}{l}\text { Construction } \\
\text { completed }\end{array}$ & $\begin{array}{l}\text { Building with no } \\
\text { other functional } \\
\text { attribute (FSB) } \\
\text { assigned }\end{array}$ & Brick & 2 & 184.69 \\
\hline \multirow{3}{*}{6} & $\begin{array}{l}\text { Construction } \\
\text { completed }\end{array}$ & $\begin{array}{l}\text { Single-family } \\
\text { building }\end{array}$ & Brick & 2 & 149.49 \\
\hline & $\begin{array}{l}\text { Construction } \\
\text { completed }\end{array}$ & $\begin{array}{l}\text { Building with no } \\
\text { other functional } \\
\text { attribute (FSB) } \\
\text { assigned }\end{array}$ & - & 1 & 68.40 \\
\hline & $\begin{array}{l}\text { Construction } \\
\text { completed }\end{array}$ & $\begin{array}{l}\text { Building with no } \\
\text { other functional } \\
\text { attribute (FSB) } \\
\text { assigned }\end{array}$ & - & 1 & 43.44 \\
\hline
\end{tabular}




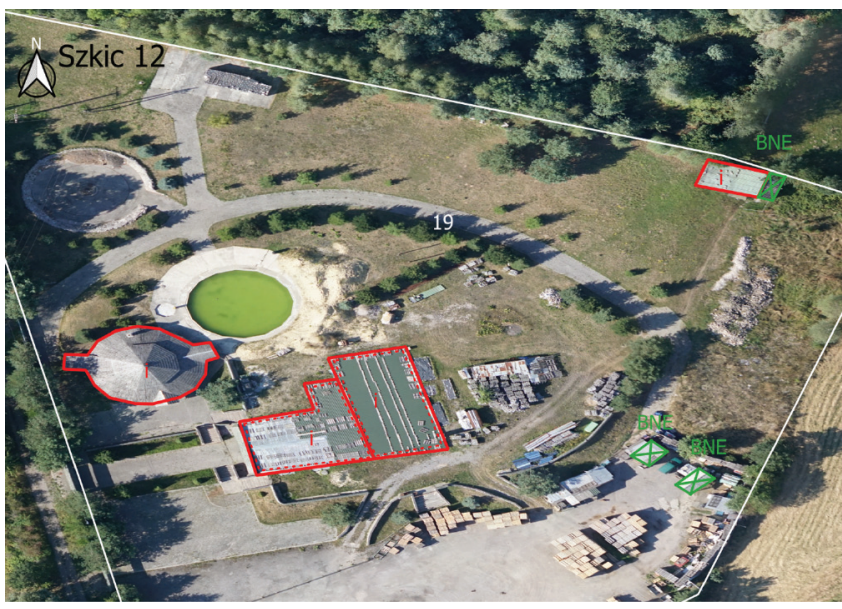

Source: Authors' study

Fig. 9. Sketch No. 12

Table 6. Attributes of buildings in Sketch No. 12

\begin{tabular}{|c|l|l|c|c|c|}
\hline $\begin{array}{c}\text { Plot } \\
\text { number }\end{array}$ & Building status & Building's function & Material & Number of storeys & $\begin{array}{c}\text { Area } \\
{\left[\mathrm{m}^{2}\right]}\end{array}$ \\
\hline \multirow{4}{*}{19} & $\begin{array}{l}\text { Construction } \\
\text { completed }\end{array}$ & $\begin{array}{l}\text { Building with no other } \\
\text { functional attribute } \\
\text { (FSB) assigned (shed) }\end{array}$ & Brick & 1 & 249.63 \\
\cline { 2 - 6 } & $\begin{array}{l}\text { Construction } \\
\text { completed }\end{array}$ & $\begin{array}{l}\text { Building with no other } \\
\text { functional attribute } \\
\text { (FSB) assigned }\end{array}$ & - & 1 & 54.12 \\
\cline { 2 - 6 } & $\begin{array}{l}\text { Under } \\
\text { construction }\end{array}$ & $\begin{array}{l}\text { Building with no other } \\
\text { functional attribute } \\
\text { (FSB) assigned }\end{array}$ & - & - & 239.74 \\
\hline \multirow{2}{*}{$\begin{array}{l}\text { Under } \\
\text { construction }\end{array}$} & $\begin{array}{l}\text { Building with no other } \\
\text { functional attribute } \\
\text { (FSB) assigned }\end{array}$ & - & - & 260.60 \\
\hline
\end{tabular}




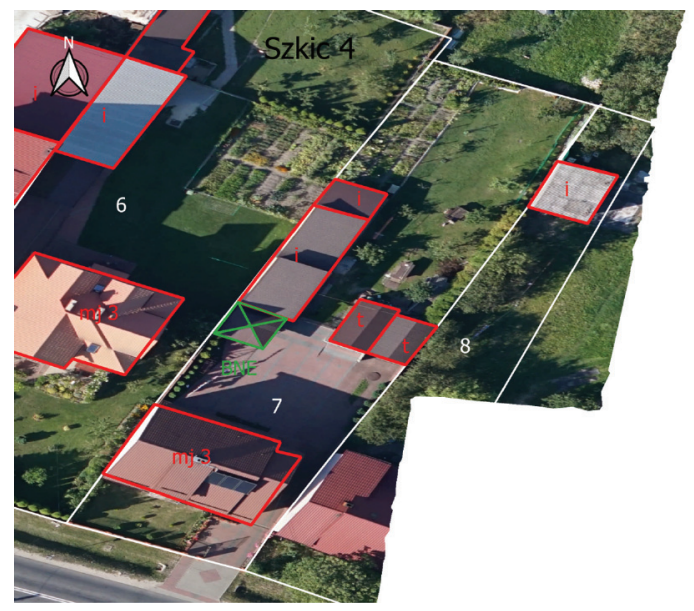

Source: Authors's study

Fig. 10. Sketch No. 4

Table 7. Attributes of buildings in Sketch No. 4

\begin{tabular}{|c|l|l|c|c|c|}
\hline $\begin{array}{c}\text { Plot } \\
\text { number }\end{array}$ & Building status & Building's function & Material & Number of storeys & $\begin{array}{c}\text { Area } \\
{\left[\mathrm{m}^{2}\right]}\end{array}$ \\
\hline \multirow{7}{*}{7} & $\begin{array}{l}\text { Construction } \\
\text { completed }\end{array}$ & $\begin{array}{l}\text { Single-family } \\
\text { building }\end{array}$ & Brick & 3 & 120.30 \\
\cline { 2 - 6 } & $\begin{array}{l}\text { Construction } \\
\text { completed }\end{array}$ & $\begin{array}{l}\text { Building with no } \\
\text { other functional } \\
\text { attribute (FSB) } \\
\text { assigned }\end{array}$ & Brick & 1 & 65.28 \\
\cline { 2 - 6 } & $\begin{array}{l}\text { Construction } \\
\text { completed }\end{array}$ & $\begin{array}{l}\text { Building with no } \\
\text { other functional } \\
\text { attribute (FSB) } \\
\text { assigned }\end{array}$ & - & 1 & 13.68 \\
\cline { 2 - 6 } & $\begin{array}{l}\text { Construction } \\
\text { completed }\end{array}$ & Single-storey garage & - & 1 & 16.44 \\
\cline { 2 - 6 } & $\begin{array}{l}\text { Construction } \\
\text { completed }\end{array}$ & Single-storey garage & - & 1 & 30.70 \\
\hline \multirow{2}{*}{6} & $\begin{array}{l}\text { Construction } \\
\text { completed }\end{array}$ & $\begin{array}{l}\text { Building with no } \\
\text { other functional } \\
\text { attribute (FSB) } \\
\text { assigned }\end{array}$ & Brick & 1 & 1 \\
\hline
\end{tabular}




\section{Conclusions}

This publication presents the way of using an orthophotomap to modernize and update Land and Building Records, as well as defining the functions and other attributes of buildings located above the object of analysis. The results obtained from the photogrammetric mission flight and the results of the identification itself are satisfactory. However, while developing the present study, problems that may arise during the analysis of the obtained results were observed. One of the biggest disadvantages when assigning attributes and determining the function of a building was the difficulty of having numerous trees covering the façade of that building. Where the trees next to the buildings covered a significant part of the façade, as well as the roof itself, this made it difficult to read not only the number of storeys, but it also hindered the calculation of the exact area of the building. Another complication encountered during the development of the study was the difficulty to distinguish clearly between the functions (uses) of the object - namely, between the farm building (in the case of owner not having the farmer's status, these were buildings with no other FSB - i.e. functional attribute specified) and the garages. Due to the small surfaces and the similarity of garage and utility farming buildings, it was problematic to identify the façades of the said buildings. The photogrammetric mission flight significantly speeds up the updating of Land and Building Records, due to the large amount of information obtained from the development of results, and it reduces the costs of performing this type of work. Despite the use of flying devices, it is necessary that the information which is either impossible to obtain or uncertain must be clarified during the field interview or the conversation with the owners. Currently, the geodetic law in force in Poland requires the public administration body to keep and update the Land and Building Survey. The records are established and kept in an IT system based on computer databases [based on the Regulation of the Minister of Regional Development and Construction of March 29, 2001 - Rozporządzenie 2001]. These databases are part of the geodetic and cartographic resource. On the basis of the computer databases developed for each district, reports are created showing data on the records of land, buildings, premises, files of buildings and premises as well as cadastral maps.

The main objective of the EGiB modernization and updating is primarily to determine the area of land for individual plots, according to their actual use [Noszczyk and Hernik 2013]. The land listed in the records is divided into: agricultural land, woodland and forest, built-up and urbanized land, semi-natural land, wetland and bodies of water, and other areas. Very often, on land record maps, you can notice inaccuracies in the designation of land under buildings or their complete absence. Many properties have arable land listed at sites of buildings, which is contrary to the requirements of operating the EGiB Land and Building Records.

This is due to deficiencies in updating and introducing the newest buildings to the map, or the lack of systematic modification and updating of the database. Consequently, there are shortcomings in taxes in the municipality's budget and a large disproportion in payments for land between neighbours who in fact own the same type of built-up 
land - resulting from erroneous uses (usually agricultural) listed under the existing building. Each building listed in the Land and Building Records must have its function, area calculated from the contours, building status, year of construction, as well as wall material and other additional attributes assigned to them. In line with the Regulation on Land and Building Records, building functions can be broken down into type, class, function, and attribute values.

The objective of the present publication was to make an orthophotomap of the obtained photogrammetric mission flight over the village of Tokarnia, and to identify the functions of the buildings and their attributes. This study showed the possibilities of using unmanned aerial vehicles for the preparation of sketches and studies related to EGiB. It presented the method of creating an orthophotomap from images taken during a photogrammetric mission flight over the examined object, as well as information that can be obtained from such a flight.

Each of the types, classes and functions has its own unique attribute value to increase the readability and expound the differences between similar attributes. Each function of the building represents its use and functional purpose. Amendments to the EGiB Regulation, effective from 1 January 2014, changed the scope of obtaining information about buildings. Pursuant to Article 63a, in addition to the contour of the building and its blocks, the land and building records database may disclose construction objects permanently connected with the building, such as: terrace, porch, vestibule, stairs, support, ramp, entrance to the underground, or ramp for persons with disabilities [Regulation by the Minister of Regional Development and Construction of March 29, 2001 - Rozporządzenie 2001].

\section{References}

Burdziakowski P. 2016. Przegląd budowy i funkcjonalności współczesnych bezzałogowych statków powietrznych do celów fotogrametrycznych. Biuletyn Wojskowej Akademii Technicznej.

Eisenbeiß H. 2009. UAV Photogrammetry. Dissertation. Institut für Geodäsie und Photogrammetrie an der ETH, Zürich, Mitteilungen.

Kędzierski M. 2013. Analiza możliwości wykonania aerotriangulacji zdjęć cyfrowych pozyskanych kamerą niemetryczną zamontowaną na pokładzie bezzałogowego statku latającego bez systemu GPS/INS. Biuletyn Wojskowej Akademii Technicznej.

Leśkiewicz K. 2016. Z prawnej problematyki aktualizacji ewidencji gruntów i budynków. Przegląd Prawa Rolnego.

Markiewicz J., Radziszewska W., Wójcik J. 2012. Zastosowanie metod fotogrametrycznych w kształtowaniu przestrzeni na obszarach wiejskich. In: Nowe trendy w naukach inżynieryjnych, 103-111.

Noszczyk T., Hernik J. 2016. Kompleksowa modernizacja ewidencji gruntów i budynków. Acta Sci. Pol., series Formatio Circumiectus 15(1).

Nowobilski T. 2020. Bezzałogowe statki powietrzne w kontroli obiektów budowlanych. Builder, 24, 2, 18-20.

Piech I., Kwinta A., Krzyszycha M. 2018. Receiving Data from UAV for Geodetic Road Inventary. Geomatics and Environmental Engineering, 12, 2. 
Plichta, A., Wyczałek M., Wyczałek I. 2017. Opracowanie części graficznej ewidencji gruntów i budynków w oparciu o zdjęcia lotnicze z pokładu UAV. Zeszyty Naukowe, Inżynieria Środowiska. Uniwersytet Zielonogórski, 165(45), 36-48.

Rozporządzenie Ministra Rozwoju Regionalnego i Budownictwa z dnia 29 marca 2001 r. w sprawie ewidencji gruntów i budynków (Dz. U. z 2019 r. poz. 393).

www.mapy.geoportal.gov.pl

www.sony.pl

Dr inż. Izabela Piech

University of Agriculture in Krakow

Department of Land Surveying, Cadastre and Photogrammetry

30-198 Kraków, ul. Balicka 253a

Correspondence address:

31-120 Kraków, al. Mickiewicza 21

e-mail: rmpiech@cyf-kr.edu.pl

ORCID: 0000-0002-6710-4387

Mgr inż. Mateusz Kopciara

University of Agriculture in Krakow

Department of Land Surveying, Cadastre and Photogrammetry

30-198 Kraków, ul. Balicka 253a

Correspondence address:

31-120 Kraków, al. Mickiewicza 21

e-mail: mateusz.kopciara@student.urk.edu.pl 